\title{
O-Sulfate Esters of Hydroxy Amino Acids in Hydrolyzates of Proteoglycans ${ }^{1}$
}

\author{
DOMINIC D. DZIEWIATKOWSKI, RICK L. RIOLO AND \\ VINCENT C. HASCALL
}

Dental Research Institute, The University of Michigan, Ann Arbor, Michigan 48104

Received April 5, 1972; accepted June 23, 1972

Proteoglycans, macromolecules isolated from connective tissues, contain large proportions of sulfated glycosaminoglycans covalently attached to protein (1). Amino acid (AA) analyses of acid hydrolyzates of proteoglycans by the methods of Spackman, Stein, and Moore (2) contain variable amounts of unidentified ninhydrin-reactive materials which elute before aspartic acid. Some of these materials appear ncar the position of cysteic acid in the analyses even when precautions are taken to prevent its formation (3). It seemed possible that these peaks represent products of reactions between hydroxy amino acids and/or hexosamines with sulfate residues released during acid hydrolysis of the proteoglycans. This suggestion is reinforced by the report of Murray and Milstein (4), who observed the formation of the $O$-sulfates of serine and threonine when proteins were hydrolyzed in the presence of small amounts of sulfate. Further examination of the literature revealed that, earlier, Moore (5) had cautioned against preparing hydrolyzates in the presence of appreciable quantities of sulfate or phosphate because he found that significant amounts of serine were converted to serine $O$-sulfate in a model system containing inorganic sulfate. Indeed, more than 25 years ago, Reitz et al. (6) noted that mild treatment of proteins with sulfuric acid led to the formation of sulfate esters of the hydroxy amino acids.

This paper describes the results of experiments which attempt to identify these ninhydrin-positive materials. $O$-Sulfate esters of hydroxyamino acids were synthesized and a chromatographic system was developed for separating and quantitating them.

${ }^{1}$ This work was supported by U. S. Public Health Service Grant DE-02731. 442

Copyright (C) 1972 by Academic Press, Inc. All rights of reproduction in any form reserved. 


\section{METHODS AND MATERIALS}

\section{(1) Preparation of O-Sulfate Esters of Hydroxyamino Acids}

Amino acids and galactosamine $\cdot \mathbf{H C l}$ were purchased from Schwarz/ Mann Research Laboratories. Potassium L-serine $O$-sulfate, potassium $\mathrm{L}$-hydroxyproline $O$-sulfate, and potassium L-tyrosine $O$-sulfate were prepared by the method of Tudball (7). In the preparation of potassium L-threonine $O$-sulfate, $500 \mathrm{mg}$ of $\mathrm{L}$-threonine was dissolved in $1 \mathrm{ml}$ of $\mathrm{H}_{2} \mathrm{SO}_{4}$ (sp.gr. 1.84) at room temperature and then set aside in vacuo over $\mathrm{CaCl}_{2}$ for $1 \mathrm{hr}$. Instead of pouring the reaction mixture into $100 \mathrm{ml}$ of a $7 \%$ solution of $\mathrm{Ba}(\mathrm{OH})_{2} \cdot 8 \mathrm{H}_{2} \mathrm{O}$ at $4^{\circ} \mathrm{C}$ to remove excess $\mathrm{H}_{2} \mathrm{SO}_{4}$ as in the preparation of the other sulfate esters, the reaction mixture was poured into $200 \mathrm{ml}$ of cold methyl ethyl ketone, as suggested by Dodgson et al. (8). The syrup which separated at the bottom of the beaker was repeatedly triturated in cold methyl ethyl ketone and ethyl ether. After removal of the residual ether in vacuo the material was dissolved in 10 $\mathrm{ml}$ of water.

For each sulfate ester, the concentrate was passed through a $1 \times 20$ $\mathrm{cm}$ column of Dowex $50\left(\mathrm{H}^{+}\right)$, and the column was washed with $30 \mathrm{ml}$ of water (7). The unreacted amino acids were retained on the column. Each of the eluates was combined with the respective water wash and the $\mathrm{pH}$ was adjusted to $7.0-7.2$ with a $5 \%$ solution of $\mathrm{KOH}$. The neutralized solutions were reduced in volume to $3-5 \mathrm{ml}$ in a rotary evaporator at $45^{\circ}$. The potassium salts of the esters were then precipitated by the dropwise addition of absolute ethanol at room temperature.

After $3-4 \mathrm{hr}$ at $4^{\circ}$ the solid samples were isolated by filtration, using $15 \mathrm{ml}$ funnels with medium-porosity sintered-glass plates. They were washed repeatedly with ethanol and then with ethyl ether. The samples were dried overnight in vacuo over $\mathrm{CaCl}_{2}$ and for 4 days in vacuo over $\mathrm{P}_{2} \mathrm{O}_{5}$ before analysis.

(2) Formation of O-Sulfate Esters of Hydroxy Amino Acids in Presence of Potassium Sulfate under Conditions Simulating Acid

\section{Hydrolysis of Proteins}

$5 \mathrm{mg}$ of L-serine, L-threonine, L-hydroxyproline, and L-tyrosine were each mixed with $50 \mathrm{mg}$ of $\mathrm{K}_{2} \mathrm{SO}_{4}$ and $2 \mathrm{ml}$ of $6 \mathrm{~N} \mathrm{HCl}$ in 16 by $150 \mathrm{~mm}$ test tubes. After evacuating and sealing, the tubes were heated at $110^{\circ} \mathrm{C}$ for $24 \mathrm{hr}$. Samples of the amino acids in the absence of $\mathrm{K}_{2} \mathrm{SO}_{4}$ were similarly treated with $6 \mathrm{~N} \mathrm{HCl}$. The simulated hydrolyzates were evaporated to dryness in an evacuated desiccator at room temperature, using $\mathrm{CaCl}_{2} / \mathrm{NaOH}$ as the desiccant. Each residue was dissolved in citrate buffer, $\mathrm{pH} 2.2$, and aliquots were analyzed for the amounts of the 
$O$-sulfate ester and of the free amino acid present, using the long column on a Beckman amino acid analyzer (2).

The extent to which the $O$-sulfate esters could form under the conditions of hydrolysis and drying as above was also determined when 2 or $1 \mathrm{mg}$ of each of the amino acids was mixed with $25 \mathrm{mg}$ of $\mathrm{K}_{2} \mathrm{SO}_{4}$.

Ikawa and Snell (9) suggested that $O$-sulfate esters of amino acids may form during the evaporation procedure rather than during hydrolysis. This possibility was checked in two ways. In one case, $5 \mathrm{mg}$ samples of L-serine were heated with 50 or $100 \mathrm{mg} \mathrm{K}_{2} \mathrm{SO}_{4}$ and $2 \mathrm{ml}$ of $6 \mathrm{~N} \mathrm{HCl}$, as above. Then, one-half of each was dried at room temperature over $\mathrm{CaCl}_{2} / \mathrm{NaOH}$ in an evacuated desiceator and the other half was brought to dryness in a flash evaporator at $45^{\circ}$. In the second case, $5 \mathrm{mg}$ of L-serine and $5 \mathrm{mg}$ of $\mathrm{L}$-threonine were each mixed with $50 \mathrm{mg}$ of $\mathrm{K}_{2} \mathrm{SO}_{4}$ and dissolved in $2 \mathrm{ml}$ of $6 \mathrm{~N} \mathrm{HCl}$. Immediately thereafter, the solutions were set aside to evaporate at room temperature over $\mathrm{CaCl}_{2} / \mathrm{NaOH}$ in an evacuated desiccator. All the residues were dissolved in citrate buffer, $\mathrm{pH} 2.2$, and analyzed as above.

(3) Separation and Determination of O-Sulfate Esters of Hydroxyamino Acids and Cysteic Acid on Dowex 1-X10 Resin

Fine particles of Dowex 1-X10 resin in the chloride form were obtained by stirring portions of the resin $(200-400$ mesh) in distilled water and allowing the slurry to settle for $5 \mathrm{~min}$. Fine particles which had not settled in this period of time were used to prepare a 0.9 by $60 \mathrm{~cm}$ column. It was equilibrated with a citrate buffer of $\mathrm{pH} 2.20 ; 10$ liters of this buffer contained $196.0 \mathrm{gm}$ sodium citrate $\cdot 2 \mathrm{H}_{2} \mathrm{O}, 170 \mathrm{ml}$ concentrated $\mathrm{HCl}, 25 \mathrm{ml}$ thiodiglycol, and $3 \mathrm{ml}$ pentachlorophenol. The $\mathrm{pH}$ was adjusted to 2.20 with either concentrated $\mathrm{HCl}$ or $10 \mathrm{~N} \mathrm{NaOH}$, if necessary.

With the column at $56^{\circ} \mathrm{C}$ and the flow rates adjusted to $68 \mathrm{ml} / \mathrm{hr}$ for the buffer and $34 \mathrm{ml} / \mathrm{hr}$ for ninhydrin, the effluent volume in which each of the $O$-sulfate esters and cysteic acid appeared was determined. This was done by using the $O$-sulfate esters singly and in combination with each other as well as in the presence of cysteic acid. The absorbance for hydroxyproline $O$-sulfate in the analytical system was greater at $440 \mathrm{~nm}$ than at $570 \mathrm{~nm}$ as is typical for imino acid derivatives.

\section{(4) Observations on Hydrolyzates of Proteoglycans}

$10 \mathrm{mg}$ portions of proteoglycan isolated from bovine nasal cartilage and designated as PGS (10), were hydrolyzed with or without the addition of $25 \mathrm{mg}$ of $\mathrm{K}_{2} \mathrm{SO}_{4}$ for $20 \mathrm{hr}$ at $110^{\circ} \mathrm{C}$ in evacuated and sealed tubes; $2 \mathrm{ml}$ of $6 \mathrm{~N} \mathrm{HCl}$ was used for each sample. The hydrolyzates were evaporated to dryness either at $25^{\circ} \mathrm{C}$ over $\mathrm{CaCl}_{2}$ and $\mathrm{NaOH}$ pellets in an 
evacuated desiccator or at $45^{\circ}$ in a flash evaporator. Solutions of the residues were analyzed on columns of UR-30 resin with a Beckman amino acid analyzer according to Spackman, Stein, and Moore (2) or by the use of a column of Dowex 1 resin as in 3 above.

Because galactosamine constitutes about $25 \%$ of PGS (10), a control experiment was done in which $5 \mathrm{mg}$ portions of galactosamine $\mathrm{HCl}$ were hydrolyzed with or without the addition of $25 \mathrm{mg}$ of $\mathrm{K}_{2} \mathrm{SO}_{4}$. The hydrolyzates were treated as above and analyzed on the UR-30 resin as described for PGS.

\section{RESULTS}

\section{(1) Synthesis of Reference O-Sulfate Esters}

In a typical experiment, starting with $500 \mathrm{mg}$ of an amino acid, 340 $\mathrm{mg}$ of potassium L-serine $O$-sulfate, $760 \mathrm{mg}$ of potassium L-threonine $O$-sulfate, $610 \mathrm{mg}$ of potassium L-hydroxyproline $O$-sulfate, and $810 \mathrm{mg}$ of potassium L-tyrosine- $O$-sulfate were obtained. Each preparation yielded only one component on the long column of a Beckman amino acid analyzer. There was no indication that any of the preparations contained any of the respective parent amino acid.

The analytical values for the sulfate esters are summarized in Table 1. The observed values are in reasonable agreement with expected values for the monopotassium salts. Furthermore, the infrared spectra of these esters confirm that they are $O$-sulfate esters. There was no absorption in the region of $3320 \mathrm{~cm}^{-1}$, where the unsubstituted hydroxyl group of the parent amino acids would absorb, whereas, there were strong absorp-

TABLE 1

Composition of $O$-Sulfate Esters of Hydroxyamino Acids

(As monopotassium salts)

\begin{tabular}{|c|c|c|c|c|c|c|c|c|}
\hline \multirow[b]{2}{*}{ Element } & \multicolumn{2}{|c|}{$\begin{array}{l}\text { Serine } O \text {-sulfate } \\
\mathrm{KC}_{3} \mathrm{H}_{6} \mathrm{O}_{6} \mathrm{SN}\end{array}$} & \multicolumn{2}{|c|}{$\begin{array}{c}\text { Threonine } \\
O \text {-sulfate } \\
\mathrm{KC}_{4} \mathrm{H}_{8} \mathrm{O}_{6} \mathrm{SN}\end{array}$} & \multicolumn{2}{|c|}{$\begin{array}{c}\text { Hydroxyproline } \\
\text { O-sulfate } \\
\mathrm{KC}_{5} \mathrm{H}_{8} \mathrm{O}_{6} \mathrm{SN}\end{array}$} & \multicolumn{2}{|c|}{$\begin{array}{c}\text { Tyrosine } \\
O_{-s u l f a t e} \\
\mathrm{KC}_{9} \mathrm{H}_{10} \mathrm{O}_{6} \mathrm{SN}\end{array}$} \\
\hline & $\begin{array}{c}\text { Theory } \\
\%\end{array}$ & $\begin{array}{c}\text { Found } \\
\%\end{array}$ & $\begin{array}{c}\text { Theory } \\
\%\end{array}$ & $\begin{array}{c}\text { Found } \\
\%\end{array}$ & $\begin{array}{c}\text { Theory } \\
\text { To }_{0}\end{array}$ & $\begin{array}{c}\text { Found } \\
\%\end{array}$ & $\begin{array}{c}\text { Theory } \\
\%\end{array}$ & $\begin{array}{l}\text { Found } \\
\%\end{array}$ \\
\hline $\mathbf{N}$ & 6.28 & 6.35 & 5.91 & 5.96 & 5.62 & 5.52 & 4.68 & 4.64 \\
\hline S & 14.35 & 14.43 & 13.50 & 13.53 & 12.85 & 13.02 & 10.70 & 10.90 \\
\hline $\mathbf{K}$ & 17.49 & 16.91 & 16.46 & 16.74 & 15.66 & 16.06 & 12.96 & 13.17 \\
\hline
\end{tabular}

Before analysis the samples were redried at $100^{\circ} \mathrm{C}$ in vacuo over $\mathrm{P}_{2} \mathrm{O}_{5}$ for $3 \mathrm{hr}$. Nitrogen was determined by a micro-Kjedahl procedure. Sulfur was determined as barium sulfate following hydrolysis in $0.1 \mathrm{~N} \mathrm{HCl}$ for $2 \mathrm{hr}$. Values for potassium were calculated from weight of the ash $\left(\mathrm{K}_{2} \mathrm{SO}_{4}\right)$ remaining after incineration in a muffle furnace at $500^{\circ}$. 
tion bands in the ranges of $1210-1250 \mathrm{~cm}^{-1}$ and $770-810 \mathrm{~cm}^{-1}$, characteristic of $O$-sulfate esters (11).

The $O$-sulfate esters were eluted from a $0.9 \times 69 \mathrm{~cm}$ column of UR-30 resin (Beckman) with a citrate buffer at $\mathrm{pH} 3.25$ between 17.0 and 21.5 min and could not be readily distinguished from cysteic acid with an elution time of 18.5 min (Table 2).

\section{(2) Formation of O-Sulfate Esters during Simulated Hydrolysis and Evaporation}

After simulated hydrolysis of serine, threonine, hydroxyproline, or tyrosine with $6 \mathrm{~N} \mathrm{HCl}$ in the presence of potassium sulfate for $24 \mathrm{hr}$ at $110^{\circ} \mathrm{C}$ and subsequent evaporation over. $\mathrm{CaCl}_{2} / \mathrm{NaOH}$ in an evacuated desiccator at room temperature, different amounts of the respective $O$-sulfate esters were found. The amount of an ester found did not seem to vary consistently as the concentration of either the amino acid or potassium sulfate was varied (Table 3 ). The formation of $O$-sulfate serine and $O$-sulfate threonine occurred more readily than $O$-sulfate hydroxyproline or $O$-sulfate tyrosine. Comparable results were obtained if an amino acid was mixed with potassium sulfate and $6 \mathrm{~N} \mathrm{HCl}$ and the mixture was then allowed to evaporate over $\mathrm{CaCl}_{2} / \mathrm{NaOH}$ in an evacuated desiccator at room temperature without the simulated hydrolysis step. On the other hand, if either a simulated hydrolyzate or the mixture of an aunino acid, potassium sulfate, and $6 \mathrm{~N} \mathrm{HCl}$ was quickly evaporated to ciryness, using a rotary evaporator at $45^{\circ}$, little or no $O$-sulfate ester was detected, as is shown for serine in Table 4 . Further, if acid hydrolyzaies of proteoglycans are rapidly evaporated at elevated temperatures, less ninhydrin-reactive material is present in the region of cysteic acid.

Treatment of the amino acids with $6 \mathrm{~N} \mathrm{HCl}$ in the absence of potas-

TABLE 2

Comparison of Elution Time of $O$-Sulfate Esters and Respective Hydroxy Amino Acids

\begin{tabular}{lclc}
\hline \multicolumn{1}{c}{ Amino acid } & $\begin{array}{c}\text { Elution time, } \\
\text { min }\end{array}$ & \multicolumn{1}{c}{ O-Sulfate ester } & $\begin{array}{c}\text { Elution } \\
\text { time, min }\end{array}$ \\
\hline Hydroxyproline & 44.5 & Hydroxyproline $O-\mathrm{SO}_{4}$ & 17.0 \\
Serine & 56.5 & $\begin{array}{l}\text { Serine } O-\mathrm{SO}_{4} \\
\text { Threonine } O-\mathrm{SO}_{4}\end{array}$ & 18.0 \\
Threonine & 52.5 & Tyrosine $O-\mathrm{SO}_{4}$ & 18.0 \\
Tyrosine & 160.0 & & 21.5 \\
Cysteic acid & 18.5 & & \\
\hline
\end{tabular}

Analyses were carried out as suggested in "Procedures Manual," Beckman, 1966, for analysis of protein hydrolyzates, except that, as soon as a sample was delivered onto the column of UR-30 resin, the recorder was started. Citrate buffer of $\mathrm{pH} 3.25$ was changed to the citrate buffer of $\mathrm{pH} 4.30$ at $85 \mathrm{~min}$. 
HYDROXY AA $O$-SULFATE ESTERS

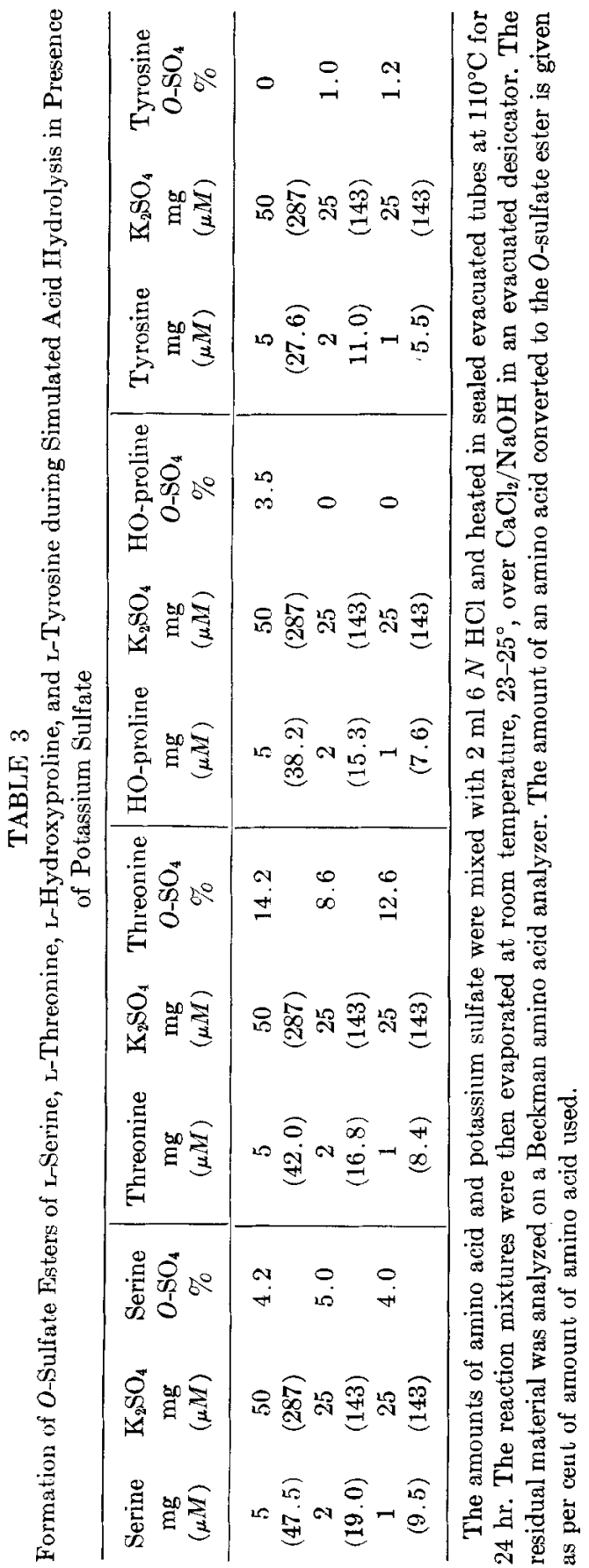


TABLE 4

Effect of Conditions of Evaporation of Simulated Hydrolyzates Containing Serine, Potassium Sulfate, and $6 \mathrm{~N} \mathrm{HCl}$ on Presence of L-Serine $O$-Sulfate

\begin{tabular}{|c|c|c|c|}
\hline \multirow{2}{*}{$\begin{array}{c}\text { Serine } \\
\mathrm{mg} \\
(\mu M)\end{array}$} & \multirow{2}{*}{$\underset{(\mu M)}{\mathrm{K}_{2} \mathrm{SO}_{\mathbf{1}}}$} & \multicolumn{2}{|c|}{ Serine $O$-sulfate $(\%)$} \\
\hline & & Evap. at $45^{\circ *}$ & Evap. at $25^{\circ} \dagger$ \\
\hline $\begin{array}{c}5 \mathrm{mg} \\
(47.5)\end{array}$ & $\begin{array}{c}50 \\
(287)\end{array}$ & 0 & 2.0 \\
\hline $\begin{array}{c}5 \mathrm{mg} \\
(47.5)\end{array}$ & $\begin{array}{c}100 \\
(\mathbf{5 7 4})\end{array}$ & 0 & 7.7 \\
\hline
\end{tabular}

The indicated amounts of serine and potassium sulfate were heated with $2 \mathrm{ml} 6 \mathrm{~N} \mathrm{HCl}$ for $24 \mathrm{hr}$ at $110^{\circ} \mathrm{C}$ in evacuated sealed tubes. The reaction mixtures were then evaporated to dryness in vacuo in a rotary evaporator* at $45^{\circ}$ or over $\mathrm{CaCl}_{2} / \mathrm{NaOH}$ in a desiccator $\dagger$ at $25^{\circ}$. The fraction of serine converted to serine $O$-sulfate is given in columns 3 and 4 .

sium sulfate gave no ninhydrin-positive material in the effuent at 17 to $21 \mathrm{~min}$. In the case of hydroxyproline an additional small peak was invariably found in the effluent at $54 \mathrm{~min}$. This was subsequently shown to be cis-4-hydroxy-D-proline (12). Such material was not detectable if the samples of hydroxyproline were not heated.

(3) Separation of O-Sulfate Esters of Hydroxyamino Acids from Cysteic Acid

The $O$-sulfate esters of serine, threonine, hydroxyproline, and tyrosine can be separated from cysteic acid on an amino acid analyzer by the use of a $0.9 \times 60 \mathrm{~cm}$ column of very fine particles of Dowex 1-X10. This is shown in Figure 1. The pattern is reproducible from run to run when dealing with a mixture of the $O$-sulfate esters and cysteic acid. The recoveries of each is of the order of $\pm 2 \%$, except for hydroxyproline $O$-sulfate, which can be recovered with a variance of $\pm 8 \%$.

\section{(4) Observations on Hydrolyzates of Proteoglycans}

When acid hydrolzates of PGS were analyzed using a column of UR30 resin according to Spackman, Stein, and Moore (2) the patterns of ninhydrin-reactive materials in the effluent for the first 50 min are as shown in Fig. 2. Three major $570 \mathrm{~nm}$ positive peaks (I, II, III) and one $440 \mathrm{~nm}$ positive peak (IV) are observed between 18 and $30 \mathrm{~min}$. The amount of material in peaks I, II, and III is substantially reduced if the hydrolyzate is flash evaporated at $45^{\circ}$ (Fig. 2A) instead of being slowly evaporated at room temperature in a desiccator (Fig. 2B).

The O-sulfate esters of the hydroxyamino acids chromatograph as the material in peak I (see Table 2). Indeed, when the hydrolyzates of PGS 


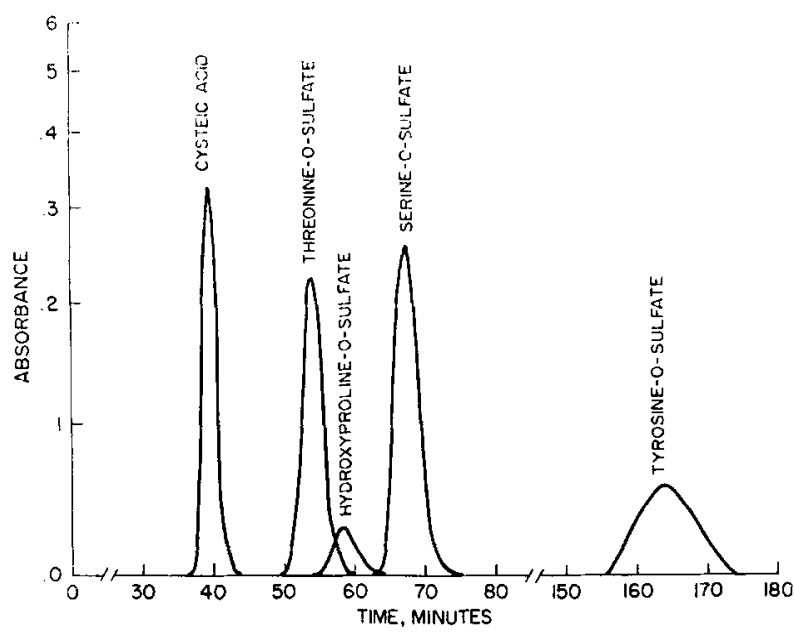

Fia. 1. Separation of $O$-sulfate esters of serine, threonine, hydroxyproline, and tyrosine from cysteic acid using Dowex 1-X10 resin. The components were eluted from a Dowex 1-X10 resin as described in "Materials and Methods." A composite of five separate chromatograms is shown but a comparable separation of the $O$-sulfate esters and cysteic acid was observed when mixtures were used. The peak for hydroxyproline $O$-sulfate is as seen at $440 \mathrm{~nm}$.



FrG. 2. Tracings of segments of chromatograms of hydrolyzates of PGS: (A) which had been evaporated to dryness in a flash evaporator at $45^{\circ}$ and (B) which had been evaporated slowly at $25^{\circ}$ in a desiceator containing $\mathrm{CaCl}_{2}$ and $\mathrm{NaOH}$. The amounts of ninhydrin-positive material at about $18 \mathrm{~min}$ and at about $25 \mathrm{~min}$ is less in A than in B. Analyses were with a column of UR-30 resin used according to Spackman, Stein, and Moore (2). 
TABLE 5

Effect of Conditions of Evaporation of Hydrolyzates of PGS on Presence of Serine $O$-Sulfate and Threonine $O$-Sulfate

\begin{tabular}{lccc}
\hline \multicolumn{1}{c}{ Sample } & $\begin{array}{c}\text { Treatment of } \\
\text { hydrolyzate }\end{array}$ & $\begin{array}{c}\text { Serine } 0 \text {-sulfate } \\
(\%)\end{array}$ & $\begin{array}{c}\text { Threonine } \\
O \text {-sulfate (\%) }\end{array}$ \\
\hline PGS & DD & 13 & 3 \\
PGS $+25 \mathrm{mg} \mathrm{K}_{2} \mathrm{SO}_{4}$ & DD & 36 & 12 \\
PGS & FE & Trace & Trace \\
PGS $+25 \mathrm{mg} \mathrm{K}_{2} \mathrm{SO}_{4}$ & FE & 10 & 4 \\
\hline
\end{tabular}

Hydrolyzates of PGS with or without added sulfate were dried as indicated (DD, dried in desiccator; $\mathrm{FE}$, flash evaporated). The contents of serine and threonine in each were determined according to Spackman et al. (2) and the contents of serine $O$-sulfate and threonine $O$-sulfate as described in the text.

were chromatographed on Dowex 1 resin as described in section 3 , serine $O$-sulfate and threonine $O$-sulfate were found in the hydrolyzates that were slowly evaporated but were barely detected in the hydrolyzates that were flash evaporated (Table 5). This table also indicates that added sulfate in the hydrolyzates of PGS greatly increases the yield of the sulfate esters.

Peaks II and III in Fig. 2A-B are reaction products, in part at least, between galactosamine and sulfate. When $\mathrm{D}$-galactosamine was "hy-



Fig. 3. Tracings of segments of chromatograms of "hydrolyzates" of D-galactosamine and $\mathrm{K}_{2} \mathrm{SO}_{4}$ : (A) which had been evaporated to dryness at $45^{\circ}$ in a flash evaporator and (B) which had been evaporated slowly at $25^{\circ}$ in a desiccator containing $\mathrm{CaCl}_{2}$ and $\mathrm{NaOH}$. The amount of ninhydrin-positive material at about 25 min is markedly less in A than in B. Analyses were with a column of UR-30 resin used according to Spackman, Stein, and Moore (2). 
drolyzed" in the presence of sulfate and flash evaporated (Fig. 3A) or desiccated (Fig. 3B), subsequent analyses on UR-30 resin (2) revealed the presence of these two components. As in the case of the $O$-sulfate esters of hydroxy amino acids, it is noteworthy that these materials were present in smaller amounts in the "hydrolyzates" which were flash evaporated than in the "hydrolyzates" which were desiccated. Neither component was formed after "hydrolysis" of galactosamine alone. Presently, they remain uncharacterized, as does the $440 \mathrm{~nm}$ positive peak IV in Fig. 2A-B.

\section{DISCUSSION}

In the analysis of proteoglycans, which are predominantly sulfated heteropolysaccharides covalently linked to protein, the observed contents of serine, threonine, and tyrosine may be underestimated unless precautions are taken to account for artifacts and destruction. It is particularly pertinent in the case of serine and threonine if exact values for these amino acids are required in making estimates of the numbers of these which might be involved in the linkage regions between the polysaccharide chains and the core protein (13-18). On the basis of the observations noted here, the possibility of observing less serine and threonine, and tyrosine, because of the formation of $O$-sulfate esters can be minimized if acid hydrolyzates of proteoglycans are evaporated to dryness rapidly and at elevated temperatures.

The urines of animals, including man, contain many sulfate esters $(19,20)$. The nature of these is for the most part unknown. The method suggested for the separation and quantitation of serine $O$-sulfate, threonine $O$-sulfate, hydroxyproline $O$-sulfate, and tyrosine $O$-sulfate may be applicable as such or after further modification, in assessing kinds and amounts of additional sulfate esters.

\section{SUMMARY}

In the preparation of hydrolyzates of proteoglycans for analysis of amino acids, ninhydrin-positive materials other than free amino acids can be generated. Some of these are $O$-sulfate esters of the hydroxy amino acids and some unknown sulfate derivatives of the hexosamines.

The amounts of the $O$-sulfate esters of the hydroxy amino acids and of the unknown derivatives of the hexosamines can be minimized if the hydrolyzates are evaporated to dryness in a flash evaporator at $45^{\circ} \mathrm{C}$.

A method is described for the separation and quantitation of the $O$-sulfate esters of serine, threonine, hydroxyproline, tyrosine, and cysteic acid. 


\section{REFERENCES}

1. Schubert, M., and Hamerman, D., "A Primer on Connective Tissue Biòchemistry," Chapter 3. Lea \& Febiger, Philadelphia, 1968.

2. Spackman, D. H., Stein, W. H., and Moore, S., Anal. Chem. 30, 1190 (1958).

3. Crestrield, A. M., Moore, S., and Stein, W. H., J. Biol. Chem. 238, 622 (1963).

4. Murray, K., and Milstein, C., Biochem. J. 105, 491 (1967).

5. Moore, S., J. Biol. Chem. 238, 235 (1963).

6. Reitz, H. C., Ferrel, R. E., Fraen kei-Conrat, H., and Olcott, H. S., J. Amer. Chem. Soc. 68, 1024 (1946).

7. Tudball, N., Biochem. J. 85, 456 (1962).

8. Dodgson, K. S., Lloyd, A. G., and Tudball, N., Biochem. J. 79, 111 (1961).

9. Ikawa, M., and Sneld, E. E., J. Biol. Chem. 236, 1955 (1961).

10. Hascall, V. C., and Sajdera, S. W., J. Biol. Chem. 244, 2384 (1969).

11. Lloyd, A. G., Tudball, N., and Dodason, K. S., Biochim. Biophys. Acta 52 , 413 (1961).

12. Dziewiatkowski, D. D., Hascall, V. C., and Riolo, R. L., Anal. Biochem. 49, No. 2 (Oct. 1972).

13. Gregohy, J. D., Lauhentr, T. C., and Ronén, L., J. Biol. Chem. 239, 3312 (1964).

14. Rodén, L., and Smith, R., J. Biol. Chem. 241, 5949 (1966).

15. Anderson, B., Hoffman, P., and Meyer, K., J. Biol. Chem. 240, 156 (1965).

16. Seno, N., Meyer, K., Anderson, B., And Hoffman, P., J. Biol. Chem. 240, 1005 (1965).

17. Seno, N., and Toda, N., Biochim. Biophys. Acta 215, 544 (1970).

18. Toda, N., and Seno, N., Biochim. Biophys. Acta 208, 227 (1970).

19. Boström, H., ANd Vestermark, A., Scand. J. Clin. Lab. Invest, 12,323 (1960).

20. Dobason, K. S., ANd Rose, F. A., in "Metabolic Conjugation and Metabolic Hydrolysis" (W. H. Fishman, ed.), Vol. 1, p. 252. Academic Press, New York, 1970. 